\title{
Correction to: Building on existing tools to improve chronic disease prevention and screening in public health: a cluster randomized trial
}

\author{
A. K. Lofters ${ }^{1,2,3,4,5^{*}}$, M. A. O'Brien ${ }^{1}$, R. Sutradhar ${ }^{5,6,9}$, A. D. Pinto ${ }^{1,7,8,10}$, N. N. Baxter ${ }^{6,13}$, P. Donnelly ${ }^{6,10,11}$, R. Elliott ${ }^{12}$, \\ R. H. Glazier ${ }^{1,5,6,7,10}$, J. Huizinga ${ }^{12}$, R. Kyle ${ }^{12}$, D. Manca ${ }^{14}$, M. A. Pietrusiak ${ }^{12}$, L. Rabeneck' ${ }^{4}$ B. Riordan ${ }^{12}$, P. Selby ${ }^{1,15}$,

Correction to: BMC Public Health 21, 1496 (2021) https://doi.org/10.1186/s12889-021-11452-x

It was highlighted that the original article [1] contained some mistakes in some of the authors' affiliations. This Correction article shows the correct affiliations. The original article has been updated.

\section{Author details}

'Department of Family \& Community Medicine, University of Toronto, Toronto, Canada. 'Women's College Hospital Research Institute, Toronto, Canada. ${ }^{3}$ Peter Gilgan Centre for Women's Cancers, Women's College Hospital, Toronto, Canada. ${ }^{4}$ Ontario Health (Cancer Care Ontario), Toronto, Canada. ${ }^{5}$ ICES, Toronto, Canada. ${ }^{6}$ Institute of Health Policy, Management and Evaluation, University of Toronto, Toronto, Ontario, Canada. ${ }^{7}$ MAP Centre for Urban Health Solutions, St. Michael's Hospital, Toronto, Canada. ${ }^{8}$ Department of Family and Community Medicine, St. Michael's Hospital, Toronto, Canada. ${ }^{9}$ Division of Biostatistics, Dalla Lana School of Public Health, University of Toronto, Toronto, Ontario, Canada. ${ }^{10}$ Dalla Lana School of Public Health, University of Toronto, Toronto, Canada. ${ }^{11}$ University of St. Andrews, Scotland, UK. ${ }^{12}$ Durham Region Health Department, Whitby, Canada. ${ }^{13}$ Melbourne School of Global and Population Health, University of Melbourne, Melbourne, Australia. ${ }^{14}$ Department of Family Medicine, University of Alberta, Edmonton, Canada. ${ }^{15}$ Centre for Addiction and Mental Health, Toronto, Canada.

${ }^{16}$ Applied Health Research Centre, St. Michael's Hospital, Toronto, Canada.

${ }^{17}$ Sunnybrook Health Sciences Centre, Toronto, Canada. ${ }^{18}$ Ontario Institute for Cancer Research, Toronto, Canada.

The original article can be found online at https://doi.org/10.1186/s12889021-11452-x

* Correspondence: aisha.lofters@wchospital.ca

'Department of Family \& Community Medicine, University of Toronto,

Toronto, Canada

'Women's College Hospital Research Institute, Toronto, Canada

Full list of author information is available at the end of the article
Published online: 21 September 2021

\section{Reference}

1. Lofters, et al. Building on existing tools to improve chronic disease prevention and screening in public health: a cluster randomized trial. BMC Public Health. 2021;21:1496. https://doi.org/10.1186/s12889-021-11452-x.

C C The Author(s). 2021 Open Access This article is licensed under a Creative Commons Attribution 4.0 International License, which permits use, sharing, adaptation, distribution and reproduction in any medium or format, as long as you give appropriate credit to the original author(s) and the source, provide a link to the Creative Commons licence, and indicate if changes were made. The images or other third party material in this article are included in the article's Creative Commons licence, unless indicated otherwise in a credit line to the material. If material is not included in the article's Creative Commons licence and your intended use is not permitted by statutory regulation or exceeds the permitted use, you will need to obtain permission directly from the copyright holder. To view a copy of this licence, visit http://creativecommons.org/licenses/by/4.0/ The Creative Commons Public Domain Dedication waiver (http://creativecommons.org/publicdomain/zero/1.0/) applies to the data made available in this article, unless otherwise stated in a credit line to the data. 